\title{
Grebneva N.N.•
}

DOI: 10.25108/2304-1730-1749.iolr.2018.55.106-121

\section{Identity of accused in a system of a subject of proving on criminal case}

\begin{abstract}
Information on personality of accused is the most important element of circumstances, which is subject to be proved during crime's investigation or, by other words, the most important element of a subject of proving on every case. All elements, which come in a subject of proving, are in close interconnection between each other. It means that requirement of establishing those or others features, which characterize a personality of accused, is also provided through proving of circumstances that relate to an event of crime; a guilt of accused, form his guilt and motives of crime's commission; circumstances, which testify about nature and size of loss caused by crime; circumstances that impact on level and nature of liability of accused; or relating to reasons and conditions, which contributed to commission of crime.
\end{abstract}

Keywords: identity of accused; a subject of proving; criminal proceedings; criminal liability; proving.

In compliance with Article 6 of the Code of Criminal Procedure of Russian Federation (hereinafter, the CCP of RF) criminal proceeding has its purpose: 1) protection of rights and legal interests of persons and organizations, which suffered from crime; 2) protection of a person from illegal and unfounded accusation, sentence, restriction his/her rights and freedoms.

Criminal prosecution and awarding to guilty persons a fair punishment to the same extent meets purpose of criminal proceedings like a refusal to prosecute the

\footnotetext{
- Grebneva Natalya Nikolayevna - PhD in Law, Tyumen Juridical Institute, Tyumen, Russia. E-mail: mopi_sid@yahoo.com
} 
innocents, releasing them from punishment, rehabilitation of each who was unfounded subjected to criminal prosecution.

The study of an identity of accused is one of the elements of a subject of proving on each criminal case. Without clarification and analysis of information on the person's identity brought to criminal liability, cannot successfully execute awarding of criminal proceedings, to determine a degree of public danger and criminal punishment of an individual committed a criminal act.

There is no single opinion among the scientist-specialists in procedure law concerning what information about accused and its volume should be included in a subject of proving $[6$, p. 14-33; 8, p. 19-21; 7, p. 31-91; 3, p. 49-64; 5, p. 23-56; 2 , p. $61-75 ; 15$, p. 39-53]. The CCP of RF provides in the most general form and in a generalized form a nature of circumstances to be proved in a criminal case, including an identity of accused. According to par. 3 of part 1 of Article 73 of the $\mathrm{CCP}$ of RF, at production of a criminal case the circumstances characterizing an identity of accused are to be proved.

Circumstances come in a subject of proving on criminal case are a certain system of ordered and interrelated elements. The subject of proving is a certain integral entity, in which, first of all, is reflected such a complex social phenomenon as a socially dangerous act that contains the signs of a crime. The internal relationship between elements of a subject of proving is determined by the nature of crime and properties of a person who committed it, and manifests itself in its integrity as a system: if no individual elements are established, it cannot to correctly judge the properties of the entire system [11, p. 12].

Necessity to prove the data on an identity of accused is also conditioned by the requirement of criminal procedure law at production of criminal case to identify the circumstances that contributed to the commission of the crime (p. 2 of Article 73 of the CCP of RF). 
Various opinions were expressed in the procedural literature concerning to a subject of criminal procedural proving доказывания [4, p. 71-80; 14, p. 221-225; 16 , p. 55-66; 12, p. 369].

Theory of proofs determines a subject of proving as a system of circumstances, which express the properties and connections of investigated event, essential for right resolution of criminal case and fulfillment of the tasks of proceedings in every concrete case [13, p. 139].

N.M. Ignatova writes that "a subject of proving might be defined as totality of the circumstances of a case, subject to mandatory determination in each criminal case, in accordance with signs of the corpus delicti and the requirements of criminal procedural law for correct resolution of a case" [5, p. 24].

Circle of these circumstances is extensive; however in any case it includes the circumstances characterizing an identity of accused.

In context of production on cases of minors, a circle of circumstances, which subject to be proved, a legislator only concretises since Article 421 of the CCP of RF says nothing about determination of any new circumstances except those, which listed in Article 73 of the CCP of RF.

In our view, analysis of Article 421 of the $\mathrm{CCP}$ of RF comes to conclusion that it concretises containing in Article 73 of the CCP of RF general requirements about proving the circumstances, which influence on degree and nature of liability of accused, circumstances characterizing an identity of accused, to number of which a legislator relates an age of minor (date, month and year of birth), level mental development and other particularities his identity (cl. 1, 2 of p. 1 of Article 421 of the CCP of RF).

This position is also kept by eminent scientists - specialists in procedural law such as Yu.I. Azarov [1, p. 15-16, 66], N.S. Manova [9, p. 6, 12], V.G. Prosvirnin [10, p. 126-127] and others. 
As for determination of such information like conditions of life and upbringing of a minor, impact elder persons to a minor (cl. 2, 3 of p. 1 of Article 421 of the CCP of RF) then we suppose that they may have the both a nature of circumstances characterizing an identity of accused and circumstances that contribute to crime commission (p. 2 of Article 73 of the CCP of RF). The foregoing allows concluding: despite a fact that the requirements of law on the need to establish data relating to an identity of accused are contained in different norms, these circumstances are closely interrelated. The relationship is that the identification of circumstances characterizing an identity of accused is carried out within a scope of a subject of proving on criminal case.

Correct resolution of issues of a criminal legal nature arising in course of criminal proceedings is one of the aims of studying an identity of accused.

Person who reached the age of sixteenth to the time of commission of crime is a subject of criminal liability. Individuals who reached the age of fourteenth to the time of commission of crime are subject to criminal liability for crimes listed in part two of Article 20 of the Criminal Code of RF (hereinafter, the CC of RF).

A person who, while committing a socially dangerous act, was in state of insanity, that is, he could not realize the actual nature and social danger of his actions (inaction) or manage them because of a chronic mental disorder, temporary mental disorder, dementia or some other morbid condition psyche is not a subject of criminal liability (Article 21 of the $\mathrm{CC}$ of RF). It is not awarded a punishment to individuals, to who after commission of crime, happened a mental disorder that makes impossible awarding and execution of punishment. Court awards such individuals an application of compulsory medical measures (p. 1 of Article 97 of the $\mathrm{CC}$ of $\mathrm{RF})$.

In addition, information about an identity of accused person is also an important for a proper qualification of an offense committed in cases where certain types of crimes contain qualifying signs relating to a subject of crime (for example, 
criminal liability for abuse of official powers (Article 285 of the CC of RF), exceeding of official powers (Article 286 of the $\mathrm{CC}$ of RF) are subjected only officials). Consequently, failure to provide data on a person, which testify his belonging to officials may lead to incorrect qualification of the deed.

Analysis of acting criminal legislation of Russian Federation allows concluding the fact that to circumstances that determine an identity of accused person the law resolves such criminal legal issues like determination of punishment kind (Articles 43, 45,47,48,49, 50, 53, 54, 55, 59 of the CC of RF), presence of circumstances that mitigate (Article 61 of the $\mathrm{CC}$ of RF) or aggravate a punishment (Article 63 of the $\mathrm{CC}$ of $\mathrm{RF}$ ), awarding softer punishment than provided for this crime (Article 64 of the $\mathrm{CC}$ of $\mathrm{RF}$ ), conditional sentence (Article 73 of the $\mathrm{CC}$ of RF), exemption from criminal liability (Articles 75, 76, 78 of the $\mathrm{CC}$ of RF), release from punishment (Articles 80.1, 81 of the $\mathrm{CC}$ of RF), postponement of serving a sentence to pregnant women and women with young children (Article 82 of the $\mathrm{CC}$ of RF) etc.

Particular importance is the circumstances characterizing an identity of accused person, for resolution of an issue of awarding a punishment at recidivism of crimes (Article 68 of the $\mathrm{CC}$ of RF). And, despite the fact that recognition of recidivism as dangerous or especially dangerous is a prerogative of court, a qualitative resolution of case is possible only if the data on this person are comprehensively and fully established at production of preliminary investigation of crimes. Among such information are, first of all, the circumstances related to the previous convictions of person. However, only the presence of data on the previous convictions of accused person is not enough, it is necessary that during preliminary investigation an investigator inquired about behavior of accused in places of deprivation of liberty, his attitude to work while serving his sentence for the crimes committed earlier, about circumstances by which the corrective effect of the previous one punishment was insufficient. 
A number of issues of a criminal procedure nature can be correctly resolved only if the necessary property of the accused identity would be established on criminal case. These include, first of all, those that allow the correct choice of the form of preliminary investigation. According to part 1 of Article 434 of the CCP of $\mathrm{RF}$, on criminal cases in respect of persons who has in a state of insanity committed an act prohibited by criminal law, or persons who, after committing a crime, have a mental disorder that makes impossible awarding a punishment or its execution, the preliminary investigation is mandatory.

In addition, if there is evidence in the case-file that accused person is a minor, or due to physical or mental disabilities, cannot exercise his right to defense independently or does not know the language in which criminal proceedings are conducted, an investigator should ensure a participation of defender (Article 51 of the CCP of RF), and, in appropriate cases, an interpreter (p. 2 of Article 18 of the CCP of RF), a teacher (psychologist) (p. 3 of Article 425 of the CCP of RF), a legal representative (Articles 426,437 of the CCP of RF).

Personality characteristics of accused are also taken into account when choosing a preventive measure against him. According to Article 99 of the CCP of $\mathrm{RF}$, when deciding the need to choose a measure of restraint in respect of accused person and determine its type, it should be taken into account the gravity of crime, an identity of accused person, his age, and state of health, marital status, occupation and other circumstances. Failure to establish at production of a case one of the circumstances listed will be impeded a correct resolution of an issue concerning to choosing a restraint measure.

\section{References}

1. Azarov Yu.I. Dokazyvanie sledovatelem obstoyatel'stv, kharakterizuyuschikh lichnost' obvinyaemogo [Proving by an investigator the 
circumstances characterizing an identity of accused person]. Dis...kand. yurid. nauk [PhD in Law Diss.]. Kiev, 1987.

2. Akhmedshin R.L. Izuchenie lichnosti prestupnika v metodike rassledovaniya prestupleniyi [Studying of an identity of criminal in method of investigation of crimes]. Tomsk, 2000, $138 \mathrm{p}$.

3. Guskova A.P. Lichnost' obvinyaemogo v ugolovnom protsesse (problem teorii i praktiki) [Identity of accused person in criminal process (problems of theory and practice)]. Dis...dokt. Yurid. nauk [Doctor of Law Diss.]. Orenburg, 1997, $388 \mathrm{p}$

4. Zinatullin Z.Z. Ugolovno-protsessual'noe dokazyvanie [Criminal procedural proving]. Posobie [Teaching aid]. Izhevsk, 2003, 177 p.

5. Ignatova N.M. Izuchenie lichnosti obvinyaemogo zaschitnikom I ispol'zovanie poluchennykh dannykh $\mathrm{v}$ khode zaschity [Studying of an identity of accused by a defender and use received data in course of defence]. Dis...kand. yurid. nauk [PhD in Law Diss.]. Izhevsk, 1997, 172 p.

6. Korshik M.G., Stepichev S.S. Izuchenie lichnosti obvinyaemogo na predvaritel'nom sledstvii [Studying of an identity of accused at preliminary investigation]. Moscow, 1969, 80 p.

7. Kurashvili G.K. Izuchenie sledovatelem lichnosti obvinyaemogo [Studying by an investigator of an identity of accused]. Moscow, 1982, 96 p.

8. Lubshev Yu.F. Lichnost' obvinyaemogo [An identity of accused]. Moscow, 1985, $62 \mathrm{p}$.

9. Manova N.S. Osobennosti predmeta dokazyvaniya po delam nesovershennoletnikh [Particularities of a subject of proving on cases of minors]. Avtoref. Dis... kand. yurid. nauk [Abstract Thesis of PhD in Law]. Saratov, 1988, $22 \mathrm{p}$. 
10. Prosvirnin V.G. Osobennosti predmeta dokazyvaniya po ugolovnym delam nesovershennolentikh [Particularities of a subject of proving on cases of minors]. Dis...kand.yurid. nauk [PhD in Law Diss.]. Voronezh, 2001, 209 p.

11. Stovpovoyi A.G. Obstoyatel'stva, kharakterizuyuschie lichnost' obvinyaemogo, kak element predmeta dokazyvaniay [Circumstances that characterize an identity of accused as an element of a subject of proving]. Avtoref. Dis... kand. yurid. nauk [Abstract Thesis of PhD in Law]. Leningrad, 1980, 25 p.

12. Strogovich M.S. Kurs sovetskogo ugolovnogo protsessa [Course of soviet criminal process]. Moscow, 1968. T. 1 [vol. 1], 468 p.

13. Teoriay dokazatel'stv $\mathrm{v}$ sovetskom ugolovnom protsesse [Theory of evidence soviet criminal process]/Pod red. N.V. Zhogina [Ed. by N.V. Zhogin]. Moscow, 1973, $528 \mathrm{p}$.

14. Ugolovno-protsessual'noe pravo Rossiyiskoyi Federatsii [Criminal procedural law of Russian Federation]. Uchebnik otv. red. P.A. Lupinskaya [Ed. by P.A. Lupinskaya]. Moscow, 2004, 815 p.

15. Florya Ye. Lichnost' prestupnika [An identity of criminal]. Dis...kand. yurid. nauk [PhD in Law Diss.]. Kishinev, 185 p.

16. Shekshuyeva O.N. Nekotorye aspekty teorii dokazatel'stv v ugolovnom protsesse [Some aspects of theory of proofs in criminal process]. Uchebnoe posobie [Teaching aid]. Moscow, 2011, $160 \mathrm{p}$. 